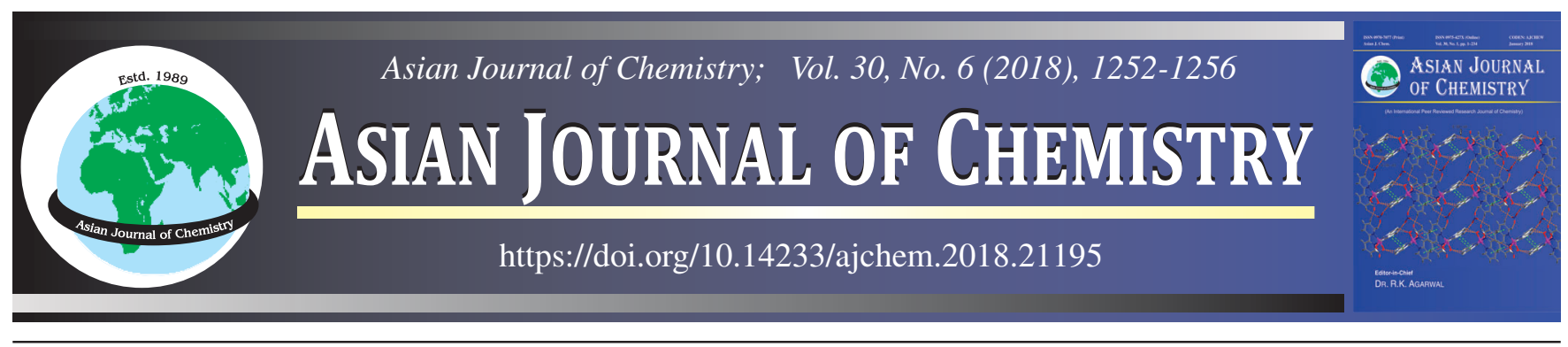

\title{
Phytochemicals and Carbohydrates Content of Some Indigenous Leafy Vegetables of Jorhat District, India
}

\author{
B.H. ChOUdHURY ${ }^{1, *}$, A.M. BARUAH ${ }^{2}$ and S. BAISHYA ${ }^{2}$
}

${ }^{1}$ Department of Biochemistry and Agricultural Chemistry, B.N. College of Agriculture, Biswanath Chariali-784 176, India

${ }^{2}$ Department of Biochemistry and Agricultural Chemistry, Assam Agricultural University, Jorhat-785 013, India

*Corresponding author: E-mail: bh_choudhury@ rediffmail.com

Received: 23 December 2017;

Accepted: 3 March 2018;

Published online: 30 April 2018;

AJC-18875

Some indigenous leafy vegetables were collected from various places of Jorhat district, Assam state of India for evaluation of phytochemicals and carbohydrates contents. The total alkaloid contents varied from $0.13-3.23 \%$, total phenol content varied from $0.25-2.2 \%$, total flavanoids content varied from $0.86-3.40 \%$, total flavanol content varied from $0.33-1.63 \%$. In case of carbohydrates, starch content varied from 18.78-56.42 \%, total soluble sugar content varied from 7.37-21.69 and reducing sugar content varied from 4.19-18.58 \%.

Keywords: Indigenous leafy vegetables, Wild, Edible parts, Phytochemicals, Carbohydrates.

\section{INTRODUCTION}

Food plants grow wild or cultivated in marginal lands and collected for food within a ecosystem. Indigenous leafy vegetables grow naturally or cultivated near the home. These are the sources of nutrients found in leaves, seed, berries, fruit, roots, tubers, stems and rhizomes [1,2]. According to FAO [3], traditional vegetables are those whose leaves, roots or fruits are used as routine vegetables by rural and urban communities through tradition. They were consumed throughout the season and play important role during famines or natural disasters. Traditional leafy vegetables are an important ingredient of diet and tradition of many indigenous world communities. Rural tribal communities in many parts of the world depend on wild plants to fulfill their dietary requirements and play crucial role in their food security [4]. Regular inclusion of wild edible plants by the ethnic groups to fulfill their dietary requirements is due to for sustenance in their dwelling environment and also become integral part of their traditional and cultural life. To earn additional income, they also sell them in their local markets [5].

Food security is related to the current availability of food. Wild leafy vegetables are considered as 'protective foods' that provide essential micronutrients and vitamins of daily dietary requirements. They are important source of phytochemicals required for lowering the risk of cardiovascular, digestive, colon cancer, anemia, fatigue, blindness and other immunity associated diseases. Wild leafy vegetables are region specific, limited acceptance, part of subsistence production system, no established market and never undergone for any breeding program [6]. Moreover, they are originating from a particular region, evolved from introduced materials over a period of time, abundant, locally adaptable, cost effective and acceptable in custom and traditions of tribal. Wild leafy vegetables are rich in 'protective elements and also have antibacterial, antiviral, antiinflammatory, antithrombotic, vasodilatory actions and antioxidant activities $[7,8]$. India has a very diverse climatic condition, agro-ecologies, tribes, topography and altitudes where cultivation of indigenous vegetables can reduce the problem of malnutrition and can fulfill the nutritional needs of the tribes and rural communities [6].

Wild leafy vegetables are important sources of vitamins like $\beta$-carotene, ascorbic acid, riboflavin and folic acid, minerals like $\mathrm{Cu}, \mathrm{Zn}, \mathrm{Mn}, \mathrm{Fe}, \mathrm{Ca}, \mathrm{P}$, carbohydrates and antioxidants. Dietary antioxidants are responsible to reduced risk of cardiovascular disease [9], diabetes [10], cancer [11] and neurodegenerative diseases [12]. In tribal and rural communities to solve the health and nutritional problem many indigenous leafy vegetables are consumed [13-17]. Nutraceutical value and antioxidant activity of wild, semi-cultivated or neglected vegetables are important area of the nutritional and phyto-therapic research throughout the world [18-26].

Wild leafy vegetables play a significant role in the dietary requirements of Assamese people due to medicinal value of herbs, cultural acceptance, easy availability, source of vitamins, minerals, fibre and used for curing various health problems of the tribal and rural consumers. During various festivals of Assam state wild leafy vegetables used as important ingredient of diet 
to fulfill nutritional requirements and cure health problems due to custom and traditional beliefs. In various region of Assam they appear as uncultivated, semi-cultivated and wild plants in marginal lands. Due to ecological, social and cultural values, wild leafy vegetables playing a significant role in the daily diet and nutritional requirement of tribal and rural communities of Assam state. However, there are no scientific reports in the modern literature regarding its phytochemicals and carbohydrates contents. So, the present study was designed to evaluate the phytochemicals and carbohydrates contents of the indigenous leafy vegetables of Jorhat district of Assam state of India.

\section{EXPERIMENTAL}

Based on survey and popularity of use by the people, some indigenous plant materials viz. Bacopa monnieri, Leucas longifolia, Enhydrafluctuans, Erynginum foetidum, Amaranthus spinosus, Pteridium aquilinum, Amaranthus viridis, Hydrocotyl rotundifolia, Alternanthera sessilis, Paederia foetida, Eclipta alba, Houttuynia cordata, Talinum triangularae, Polygonum chinense, Oxalis corniculata, Oldenlandia corymbosa, Malva sylvestris, Chrysopagon coroneriam, Trigonella foenum-graecum, Basella rubra, Chenopodium album, Stellaria media, Basella alba, Centalla asiatica and Oxallis acetosella were collected from various places of Jorhat district of Assam state. These plants were cultivated in pot in the Department of Biochemistry and Agricultural Chemistry, Assam Agricultural University, Jorhat, India and edible tender parts were harvested, washed under tape water, dried under sunshine, after drying milling were done in wily mill (IKON, Dehli) and dry powder was used for investigation.
The total alkaloid content was determined by the method given by Obadoni and Ochuko [27], total phenol content by Bray and Thorpe [28], total flavonoid content by Woisky and Salatino [29] with slight modification, flavonol content by Miliauskas et al. [30], starch content by Clegg [31], total soluble sugar content by Clegg [31] and reducing sugar content by Miller [32].

\section{RESULTS AND DISCUSSION}

The data of phytochemicals and carbohydrates content of indigenous leafy vegetables are presented in Tables 1 and 2, respectively.

Phytochemicals composition: Phytochemicals are the chemicals found in plants which have a broad protective beneficial effects like reducing inflammation, speeding healing to prevent infection, fighting cancer. etc. Phytochemicals are not essential for human being but essential for plants such as fruits and vegetables as self protecting programme helping to shield young buds, sprouts from predators, pollution, etc. Many phytochemicals are antioxidants like lycopene, quercetin, $\beta$-carotene, etc. activate body's detoxifying enzymes.

The results revealed Amaranthus spinosus (3.23\%) has the highest total alkaloid and Polygonum chinense $(0.13 \%)$ has the lowest total alkaloid content. Alkaloids have lots of beneficial effects in incuring neurological problem, cardiological problem, potent toxins, provide defense in plant and used in treating cancer. The values are higher when compared to the values obtained by Adedapo et al. [33] in leaves of C. album is $1.8 \mathrm{mg} / 100 \mathrm{~g}$. Jimoh et al. [34] found in Amaranthus asper leaves is $0.3 \mathrm{mg} / 100 \mathrm{~g}$ and Sood et al. [35] found in different cultivars of Chenopodium ranged from 0.69 to $1.67 \mathrm{mg} / 100 \mathrm{~g}$.

TABLE-1

PHYTOCHEMICALS (ON DRY WEIGHT BASIS) OF INDIGENOUS LEAFY VEGETABLES (g \%)

\begin{tabular}{|c|c|c|c|c|c|c|}
\hline S. No. & Local name & Botanical name & Total alkaloid & Total phenol & Total flavanoid & $\begin{array}{c}\text { Total flavanol } \\
(\mathrm{mg} \%)\end{array}$ \\
\hline 1 & Brahmi & Bacopa monnieri & 2.30 & 2.20 & 1.96 & 0.44 \\
\hline 2 & Doron & Leucas longifolia & 1.80 & 2.10 & 2.36 & 0.82 \\
\hline 3 & Helosi sak & Enhydra fluctuans & 2.70 & 0.47 & 1.56 & 0.42 \\
\hline 4 & Mandhania & Erynginum foetidum & 3.07 & 0.31 & 1.72 & 0.44 \\
\hline 5 & Hatikhotora & Amaranthus spinosus & 3.23 & 0.32 & 1.15 & 0.50 \\
\hline 6 & Dhekia & Pteridium aquilinum & 2.97 & 1.13 & 2.02 & 0.41 \\
\hline 7 & Khotora & Amaranthus viridis & 2.80 & 0.44 & 1.41 & 0.62 \\
\hline 8 & Saru Manimoni & Hydrocotyl rotundifolia & 3.10 & 0.44 & 2.25 & 0.45 \\
\hline 9 & Matikandori & Alternanthera sessilis & 1.50 & 0.26 & 2.32 & 0.71 \\
\hline 10 & Bhedailata & Paederia foetida & 2.10 & 1.08 & 2.94 & 0.65 \\
\hline 11 & Keheraj & Eclipta alba & 2.93 & 0.53 & 1.82 & 0.93 \\
\hline 12 & Masundori & Houttuynia cordata & 0.43 & 1.13 & 1.53 & 0.51 \\
\hline 13 & Pirali paleng & Talinum triangularae & 0.33 & 0.37 & 1.38 & 0.41 \\
\hline 14 & Madhuholang & Polygonum chinense & 0.13 & 0.49 & 1.89 & 0.47 \\
\hline 15 & Saru Tengesi & Oxalis corniculata & 0.37 & 0.39 & 1.36 & 0.50 \\
\hline 16 & Bonjaluk & Oldenlandia diffusa & 1.97 & 1.15 & 2.76 & 0.40 \\
\hline 17 & Laffa & Malva sylvestris & 0.64 & 1.22 & 2.23 & 0.37 \\
\hline 18 & Baburi & Chrysopogon coronerium & 1.20 & 1.05 & 1.78 & 0.80 \\
\hline 19 & Methi & Trigonella foenum-graecum & 1.20 & 1.33 & 2.90 & 0.52 \\
\hline 20 & Puroi (red) & Basella rubra & 0.60 & 1.18 & 2.13 & 1.39 \\
\hline 21 & Jilmil & Chenopodium album & 0.80 & 0.96 & 3.40 & 0.60 \\
\hline 22 & Morolia & Stellaria media & 0.79 & 0.44 & 1.92 & 1.63 \\
\hline 23 & Puroi (green) & Basella alba & 0.82 & 0.44 & 1.84 & 0.51 \\
\hline 24 & Bor Manimoni & Centalla asiatica & 0.83 & 0.25 & 0.86 & 0.50 \\
\hline \multirow[t]{3}{*}{25} & Bor Tangeshi & Oxalllis acetosella & 1.20 & 1.10 & 2.42 & 0.33 \\
\hline & & SED ( $( \pm)$ & 0.11 & 0.02 & 0.05 & 0.03 \\
\hline & & $\mathrm{CD}$ at $5 \%$ & $0.18 *$ & $0.03 *$ & $0.04 *$ & $0.06 *$ \\
\hline
\end{tabular}


TABLE-2

CARBOHYDRATES CONTENT (ON DRY WEIGHT BASIS) OF DIFFERENT INDIGENOUS LEAFY VEGETABLES (g \%)

\begin{tabular}{|c|c|c|c|c|c|}
\hline S. No. & Local name & Botanical name & Starch & Total soluble sugar & Reducing sugar \\
\hline 1 & Brahmi & Bacopa monnieri & 34.71 & 12.95 & 9.68 \\
\hline 2 & Doron & Leucas longifolia & 28.86 & 15.08 & 10.40 \\
\hline 3 & Helosi sak & Enhydra fluctuans & 37.52 & 16.69 & 12.72 \\
\hline 4 & Mandhania & Erynginum foetidum & 27.68 & 13.27 & 5.86 \\
\hline 5 & Hatikhotora & Amaranthus spinosus & 56.42 & 9.50 & 5.52 \\
\hline 6 & Dhekia & Pteridium aquilinum & 24.33 & 11.30 & 9.53 \\
\hline 7 & Khotora & Amaranthus viridis & 24.57 & 10.72 & 6.37 \\
\hline 8 & Saru Manimoni & Hydrocotyl rotundifolia & 34.44 & 21.69 & 18.58 \\
\hline 9 & Matikandori & Alternanthera sessilis & 35.51 & 9.98 & 7.50 \\
\hline 10 & Bhedailata & Paederia foetida & 26.35 & 16.54 & 14.13 \\
\hline 11 & Keheraj & Eclipta alba & 26.86 & 14.68 & 12.66 \\
\hline 12 & Masundori & Houttuynia cordata & 18.89 & 18.37 & 15.11 \\
\hline 13 & Pirali paleng & Talinum triangularae & 30.40 & 10.31 & 7.48 \\
\hline 14 & Madhuholang & Polygonum chinense & 18.78 & 14.73 & 13.26 \\
\hline 15 & SaruTengesi & Oxalis corniculata & 33.75 & 15.17 & 14.10 \\
\hline 16 & Bonjaluk & Oldenlandia diffusa & 20.40 & 11.19 & 10.46 \\
\hline 17 & Laffa & Malva sylvestris & 41.69 & 16.49 & 15.34 \\
\hline 18 & Baburi & Chrysopogon coronerium & 32.38 & 11.79 & 6.31 \\
\hline 19 & Methi & Trigonella foenum-graecum & 36.40 & 8.17 & 5.97 \\
\hline 20 & Puroi (red) & Basella rubra & 36.58 & 8.87 & 4.19 \\
\hline 21 & Jilmil & Chenopodium album & 29.61 & 10.34 & 7.47 \\
\hline 22 & Morolia & Stellaria media & 32.46 & 11.36 & 7.47 \\
\hline 23 & Puroi (green) & Basella alba & 20.47 & 10.66 & 6.16 \\
\hline 24 & Bor Manimoni & Centalla asiatica & 25.58 & 17.22 & 15.15 \\
\hline \multirow[t]{3}{*}{25} & Bor Tangeshi & Oxalllis acetosella & 23.87 & 7.37 & 5.10 \\
\hline & & SED ( $( \pm)$ & 0.17 & 0.04 & 0.10 \\
\hline & & $\mathrm{CD}$ at $5 \%$ & $0.28 *$ & $0.08 *$ & $0.16^{*}$ \\
\hline
\end{tabular}

The data revealed Bacopa monnieri $(2.2 \%)$ has the highest total phenol content while Centalla asiatica $(0.25 \%)$ has the lowest total phenol content. Phenolics are non-nutritive secondary metabolites which have significant health benefit and prevent various diseases. Phenols have antioxidant potential [36] and act as a reducing agents, hydrogen donators and single oxygen quenchers [37]. The values are comparable with the values obtained by various authors. Silva et al. [38] found Bauhinia forficate contains $1.66 \mathrm{~g}(\mathrm{GAE}) / 100 \mathrm{~g}$, Davilla kunthii contains $3.64 \mathrm{~g} \mathrm{GAE} / 100 \mathrm{~g}$ and Byrsonima crassifolia contains $4.55 \mathrm{~g}$ GAE/100 g total phenol conten. Sood et al. [35] reported that in various cultivars of Chenopodium total phenolic content ranged from 0.304 to $0.225 \mathrm{~g} \mathrm{GAE} / 100 \mathrm{~g}$. Kaur and Kapoor [39] reported Chenopodium album leaves contains $0.254 \mathrm{~g} \mathrm{GAE} / 100 \mathrm{~g}$ total phenol content.

The results revealed Chenopodium album $(3.40 \%)$ has the highest total flavanoids and Centalla asiatica $(0.86 \%)$ has the lowest total flavanoids content. Flavonoids are natural antioxidant which lowering the risk of coronary heart diseases prevent cardiovascular diseases, alzheimers disease, neurodegenerative diseases, diabetes, osteoporosis and lung cancer through antioxidative action and the modulation of several protein functions. The results are higher as compared with the results obtained by various authors. Sood et al. [35] reported in various cultivars of Chenopodium flavanoid content varied from 0.22 to $0.41 \mathrm{~g} / 100 \mathrm{~g}$. Adedapo et al. [33] reported $0.18 \mathrm{~g} / 100 \mathrm{~g}$ flavonoid content in the leaves of C. album.

The data revealed Stellaria media $(1.63 \%)$ has the highest total flavanol content and Oxallis acetosella $(0.33 \%)$ has the lowest total flavanol content. Flavonols and flavonones are flavonoids has antioxidant and free radical scavenging activity in vegetable [40] and show various physiological effects viz. antiallergenic, antiartherogenic, anti-inflammatory, antimicrobial, antioxidant, antithrombotic, cardioprotective and vasodilatory effects [41,42]. Similar results were obtained by various authors. Jimoh et al. [34] reported that Amaranthus asper leaves contained $0.96 \mathrm{~g} / 100 \mathrm{~g}$ total flavanols. Afolayan et al. [43] reported that $C$. album, $S$. asper, $S$. nigrum and $U$. urens contains 0.98 $\pm 0.41,0.91 \pm 0.26,0.71 \pm 0.00,0.78 \pm 0.08$ total flavonols $(\mathrm{g} / 100 \mathrm{~g})$ content, respectively.

Carbohydrates content: A reducing sugar contains aldehyde or ketone group. Due to aldehyde group sugar acts as a reducing agent. Reducing sugar in diet involved in weight loss and increased energy. Oxidation-reduction reactions create energy by the loss or gain of electrons in molecules. Oxidationreduction reactions are important for human life by providing energy source for the body. This process requires a reducing agent or oxidizing agent. Some sugars or carbohydrates act as reducing agents.

The results presented in Table- 2 revealed Amaranthus spinosus $(56.42 \%)$ has the highest starch content and Polygonum chinense (18.78\%) has the lowest starch content. Starches are carbohydrates that contribute more than $50 \%$ energy required by the people. After digestion, starch molecule converted to single molecules of glucose which provide energy to all the cells and organs in body. If body doesn't require this energy that will be stored as glycogen in liver and muscles, remaining portion will be converted to fat and stored in fat cells. Similar types of results are obtained by Aberoumand [44] in eight edible plants varies from 5.86 to $60.41 \%$. Saunders and Beciker [44] found starch content in pale-seeded leaves of A. cruentus is $48 \%$ and A. hypochondriacus is $62 \%$. 
The results revealed Hydrocotyl rotundifolia (21.69\%) has the highest total soluble sugar content and Oxallis acetosella $(7.37 \%)$ has lowest total soluble sugar content. In higher plants, total soluble sugar is the main photosynthate and main form of carbohydrate metabolism and temporary storage. The values are comparable with the values obtained by Misra and Misra [46] reported Murraya koenigii (18.76 g/100 g) contains highest total sugar content and lowest by Tridax procumbens $(18.00 \mathrm{~g} / 100 \mathrm{~g})$ among the studied 27 leafy vegetables. As per the report of Ejoh et al. [47] total soluble sugar values for Vernonia calvoana var. bitter is $2.41 \%$ and $V$. calvoana var. non-bitter is $4.83 \%$.

The data revealed Hydrocotyl rotundifolia $(18.58 \%)$ contains highest reducing sugar content and Basella rubra (4.19\%) contains lowest reducing sugar content. Reducing sugar in diet is responsible for weight loss and increased energy. Intake of high sugar-sweetened beverage is responsible for Type- 2 diabetes, obesity, hypertension and coronary heart disease. Verma et al. [48] reported Bauhinia variegata buds and flowers contain reducing sugar 1.45 and $2.35 \%$. Ejoh et al. [47] found reducing sugar values in Vernonia calvoana var. bitter and $V$. calvoana var. non-bitter ranged from 13.08 to $15.79 \%$. Imran et al. [49] found Scandix pecten-veneris contains reducing sugar $0.64 \%$.

The variation in the phytochemicals and carbohydrates contents of indigenous leafy vegetables may be due to species differences and different agroclimatic conditions. The variation may also be due to the different age of the plant, stage of plants, conditions of growth, soil fertility and environmental conditions of the plant species.

\section{Conclusion}

Indigenous leafy vegetables are weed of agriculture but these wild vegetables are considered as famine foods or wild foods in developing country. These leafy vegetables are rich source of nutrients as well as rich source of phytochemicals and carbohydrates.

\section{ACKNOWLEDGEMENTS}

The authors acknowledge to Department of Biochemistry and Agricultural Chemistry, Assam Agricultural University, Jorhat, India for providing required facilities to carry out the present investigation.

\section{REFERENCES}

1. J.A. Chweya and P.B. Eyzaguirre, The Biodiversity of Traditional Leafy Vegetables, International Plant Genetic Resources Institute (IPGRI), Rome, pp. 1-182 (1999).

2. P. Maundu and L. Guarino, Africa: Conservation and Use, 29-31 August, ICRAF-HQ, Nairobi, Kenya, pp. 66-71 (1997).

3. FAO, Report on the State of the World's Plant Genetic Resources, Prepared for the International Technical Conference on Plant Genetic Resources, Leipzig, Germany, 17-23 June (1996).

4. K. Balemie and F. Kebebew, J. Ethnobiol. Ethnomed., 2, 53 (2006); https://doi.org/10.1186/1746-4269-2-53.

5. A. Angami, P.R. Gajurel, P. Rethy, B. Singh and S.K. Kalita, Indian J. Tradit. Knowl., 5, 541 (2006).

6. S. Singh and D.R. Singh, ed.: D.R. Singh, Species Diversity of Vegetables Crops in Andaman and Nicobar Islands: Efforts and Challenges for Utilization, In: Souvenir on Innovative Technologies for Conservation and Sustainable Utilization of Island Biodiversity, CARI, Port Blair, pp. 120-129 (2012).
7. N.K. Olembo, S.S. Fedha and E.S. Ngaira, Glob. J. Pure Appl. Sci., 8, 203 (1995).

8. WHO, Report of a Joint FAO/WHO Expert Consultation. Geneva, WHO Technical Report Series, No. 916 (2003).

9. M.G.L. Hertog, P.C.H. Hollman and M.B. Katan, J. Agric. Food Chem., 40, 2379 (1992); https://doi.org/10.1021/jf00024a011.

10. J. Montonen, P. Knekt, R. Jarvinen and A. Reunanen, Diabetes Care, 27, 362 (2004); https://doi.org/10.2337/diacare.27.2.362.

11. A.F. Ekstrom, M. Serafini, O. Nyren, L.E. Hansson, W. Ye and A. Wolk, Int. J. Cancer, 87, 133 (2000); https://doi.org/10.1002/1097-0215(20000701)87:1<133::AID-IJC20> 3.0.CO;2-E.

12. D. Offen, Y. Gilgun-Sherki and E. Melamed, J. Neurol., 251, 261 (2004); https://doi.org/10.1007/s00415-004-0348-9.

13. N.L. Etkin, Int. J. Pharmacol., 34, 313 (1996); https://doi.org/10.1076/phbi.34.5.313.13246.

14. A. Pieroni, J. Ethanopharm., 70, 235 (2000); https://doi.org/10.1016/S0378-8741(99)00207-X

15. A. Pieroni, S. Nebel, C. Quave, H. Münz and M. Heinrich, J. Ethanopharm., 81, 165 (2002); https://doi.org/10.1016/S0378-8741(02)00052-1.

16. A. Pieroni, V. Janiak, C.M. Dürr, S. Lüdeke, E. Trachsel and M. Heinrich, Phytother. Res., 16, 467 (2002); https://doi.org/10.1002/ptr.1243.

17. A. Pieroni and L.L. Price, Eating and Healing: Traditional Food as Medicine, Howorth Press, Binghamton, NY, USA (2006).

18. C. Lionis, A. Faresjo, M. Skoula, M. Kapsokefalou and T. Faresjo, Lancet, 352, 1987 (1998); https://doi.org/10.1016/S0140-6736(05)61333-5.

19. L.E. Grivetti and B.M. Ogle, Nutr. Res. Rev., 13, 31 (2000); https://doi.org/10.1079/095442200108728990.

20. S. Karakaya, S.N. El and A.A. Ta, Int. J. Food Sci. Nutr., 52, 501 (2001); https://doi.org/10.1080/713671810.

21. B. Ogle, H.T.A. Dao, G. Mulokozi and L. Hambraeus, Int. J. Food Sci. Nutr., 52, 485 (2001); https://doi.org/10.1080/713671806.

22. B.M. Ogle, P.H. Hung and T.T. Tuyet, Asia Pacific J. Clin. Nutr., 10, 21 (2001); https://doi.org/10.1046/j.1440-6047.2001.00206.x.

23. B.M. Ogle, M. Johansson, H.T. Tuyet and L. Johannesson, Asia Pacific J. Clin. Nutr., 10, 216 (2001); https://doi.org/10.1046/j.1440-6047.2001.00261.x.

24. N. Johnson and L.E. Grivetti, Int. J. Food Sci. Nutr., 53, 489 (2002); https://doi.org/10.1080/09637480220164389.

25. P.L. Owen and T. Johns, Pharm. Biol., 40, 346 (2002); https://doi.org/10.1076/phbi.40.5.346.8461.

26. M. Couladis, O. Tzakou, E. Verykokidou and C. Harvala, Phytother. Res., 17, 194 (2003); https://doi.org/10.1002/ptr.1261.

27. B.O. Obadoni and P.O. Ochuko, Glob. J. Pure Appl. Sci., 8, 203 (2001).

28. H.G. Bray and W.V. Thorpe, Methods Biochem. Anal., 1, 27 (1954).

29. R. Woisky and A. Salatino, J. Apic. Res., 37, 99 (1998); https://doi.org/10.1080/00218839.1998.11100961.

30. G. Miliauskas, P.R. Venskutonis and T.A. van Beek, Food Chem., 85, 231 (2004); https://doi.org/10.1016/j.foodchem.2003.05.007.

31. K.M. Clegg, J. Sci. Food Agric., 7, 40 (1956); https://doi.org/10.1002/jsfa.2740070108.

32. G.L. Miller, Anal. Chem., 31, 426 (1959); https://doi.org/10.1021/ac60147a030.

33. A. Adedapo, F. Jimoh and A. Afolayan, Acta Polon. Pharm.-Drug Res., 68, 83 (2011).

34. F.O. Jimoh, A.A. Adedapo, A.A. Aliero, S. Koduru and A.J. Afolayan, Open Complement. Med. J., 2,7 (2010); https://doi.org/10.2174/1876391X01002010007.

35. P. Sood, R. Modgil, M. Sood and P.K. Chuhan, Ann. Food Sci. Technol. (Valahia Univ. Târgoviste), 13, 68 (2012).

36. J.M. Awika, L.W. Rooney, X. Wu, R.L. Prior and L. Cisneros-Zevallos, J. Agric. Food Chem., 51, 6657 (2003); https://doi.org/10.1021/jf034790i. 
37. S.T. Chang, J.H. Wu, S.Y. Wang, P.L. Kang, N.S. Yang and L.F. Shyur, J. Agric. Food Chem., 49, 3420 (2001); https://doi.org/10.1021/jf0100907.

38. E.M. Silva, J.N.S. Souza, H. Rogez, J.F. Rees and Y. Larondelle, Food Chem., 101, 1012 (2007);

https://doi.org/10.1016/j.foodchem.2006.02.055

39. C. Kaur and H.C. Kapoor, J. Food Sci. Technol., 37, 153 (2002); https://doi.org/10.1046/j.1365-2621.2002.00552.x.

40. D.D. Amic, D. Beslo and N. Trinagistic, Croat. Chem. Acta, 76, 55 (2003).

41. C. Manach, A. Mazur and A. Scalbert, Curr. Opin. Lipidol., 16, 77 (2005); https://doi.org/10.1097/00041433-200502000-00013.

42. E. Middleton, C. Kandaswami and T.C. Theoharides, Pharmacol. Rev., 52, 673 (2000)

43. A.J. Afolayan and F.O. Jimoh, Int. J. Food Sci. Nutr., 60, 424 (2009); https://doi.org/10.1080/09637480701777928.
44. A. Aberoumand, Res. Org. Farm., 60-71 (2011).

45. R.M. Saunders and R. Beciker, ed.:Y. Pomeranz, Amaranthus, In: Advances in Cereal Science and Technology, American Association Cereal Chemists, St. Paul, MN, USA, vol. VI, p. 357 (1984).

46. S. Misra and M.K. Misra, J. Nat. Prod. Plant Res., 4, 23 (2014).

47. R.A. Ejoh, D.V. Nkonga, G. Inocent and M.C. Moses, Pak. J. Nutr., 6, 712 (2007); https://doi.org/10.3923/pjn.2007.712.717.

48. R. Verma, M. Awasthi, R. Modgil and Y.S. Dhaliwal, Indian J. Nat. Prod. Res., 3, 242 (2012).

49. M. Imran, F.N. Talpur, M.S. Jan, A. Khan and I. Khan, J. Chem. Soc. Pak., 295, 500 (2007). 